\title{
8
}
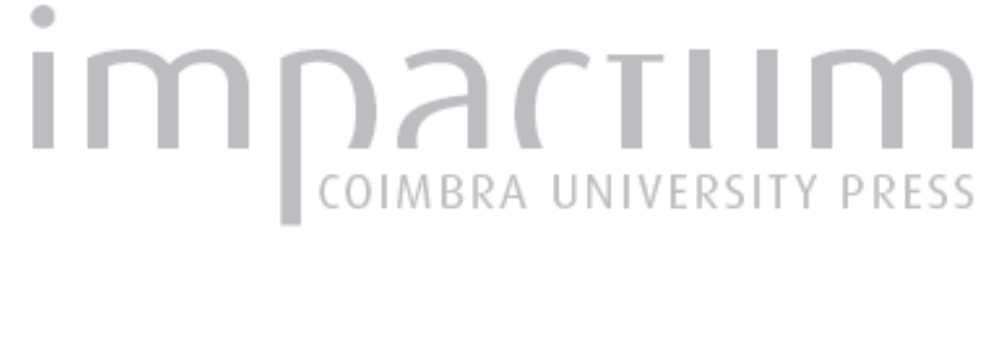

Boom and (deep) crisis in the Spanish economy: the role of the EU in its evolution

Autor(es): $\quad \begin{aligned} & \text { Etxezarreta, Miren; Navarro, Francisco; Ribera, Ramón; Soldevila, } \\ & \text { Victoria }\end{aligned}$

Publicado por: Faculdade de Direito da Universidade de Coimbra

URL

persistente:

URI:http://hdl.handle.net/10316.2/30701

DOI:

DOI:http://dx.doi.org/10.14195/0870-4260_55_1

Accessed : $\quad$ 26-Apr-2023 09:41:33

A navegação consulta e descarregamento dos títulos inseridos nas Bibliotecas Digitais UC Digitalis, UC Pombalina e UC Impactum, pressupõem a aceitação plena e sem reservas dos Termos e Condições de Uso destas Bibliotecas Digitais, disponíveis em https://digitalis.uc.pt/pt-pt/termos.

Conforme exposto nos referidos Termos e Condições de Uso, o descarregamento de títulos de acesso restrito requer uma licença válida de autorização devendo o utilizador aceder ao(s) documento(s) a partir de um endereço de IP da instituição detentora da supramencionada licença.

Ao utilizador é apenas permitido o descarregamento para uso pessoal, pelo que o emprego do(s) título(s) descarregado(s) para outro fim, designadamente comercial, carece de autorização do respetivo autor ou editor da obra.

Na medida em que todas as obras da UC Digitalis se encontram protegidas pelo Código do Direito de Autor e Direitos Conexos e demais legislação aplicável, toda a cópia, parcial ou total, deste documento, nos casos em que é legalmente admitida, deverá conter ou fazer-se acompanhar por este aviso.

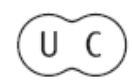


VOLUME LV

$\begin{array}{llll}2 & 0 & 1 & 2\end{array}$

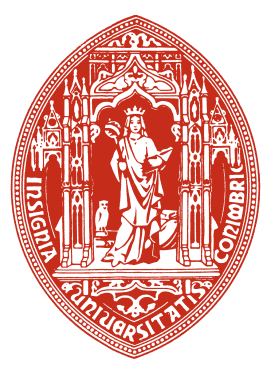




\section{BOOM AND (DEEP) CRISIS IN THE SPANISH ECONOMY: THE ROLE OFTHE EU IN ITS EVOLUTION}

\section{A brief snapshot of the Spanish economy}

Spain has historically been a poor country in relation with the rich countries of Europe. But after the development initiated in the sixties and having gone through all the process of full incorporation of the country into developed capitalism even if cut across by many specific elements ${ }^{1}$ and with its integration in the European Economic Community, gradually Spain started to feel a full member of the rich part of the world. At the beginning of the $21^{\text {st }}$ Century we find a country with a level of income and an economic structure similar to the second rank countries of the EU. Indeed, Spain became the fifth industrial power in Europe. No longer Spanish leaders considered themselves part of a poor country but members of an important industrialised country, even if in the opinion of European and World leaders it has never attained at best more than a second rank classification. It seems Spain

${ }^{1}$ As the dictatorship in the XX century, the intent of a new coup in 1981 and so on. For a detailed account of this process and its evaluation see: M. EtXezArRetA, (editor). La reestructuración del capitalismo en España. Editorial Icaria. Barcelona, 1991. 
had 'developed' at least in economic growth and industrial structure. (see Figure 1.1 and Figure 1.2).

FIgURE 1.1 - GDP Growth rate, Spain, 1971-2010

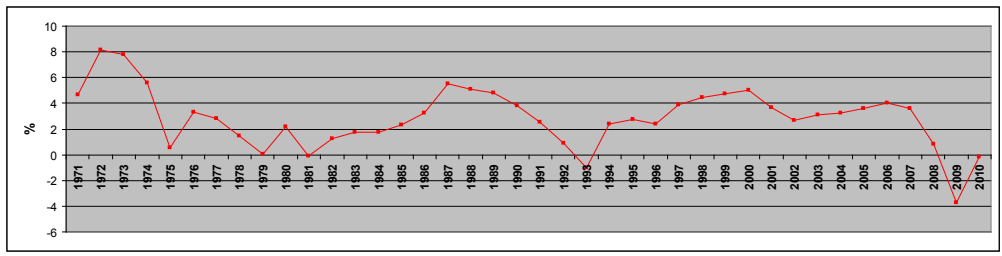

Source: Own elaboration based on OECD, 2011.

FIGURE 1.2. - Relative evolution of the GDP per capita, Spain, $(E U=100)$

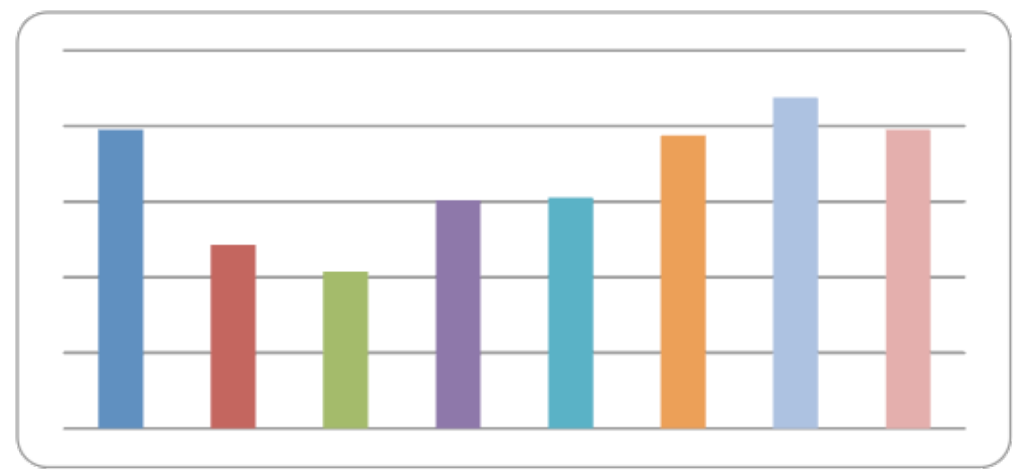

Source: Own elaboration based on OECD, 2011.

The evolution of the Spanish economy since the sixties of the past Century may be briefly described as follows: There is a first industrialisation and urbanisation drive in the sixties. Internal demand was growing due to industrialisation, urbanisation and the corresponding increased incomes and the country could export thanks to low wages and a submit- 
ted labour force. During the eighties, Spain is integrated into the EU with a productive model based in low labour costs and low level technology (automobile, food industries) and compelled to compete with European industries under the pressure of the Single Act. Increasingly the country became an interesting market for the central countries of the Union.

This productive model deteriorated with increasing world and European competitiveness (East European and Asian countries) and in 1994 unemployment was at 24,1\% of the working population. Pressure upon wages increased and especially working precariousness was used (submerged economy, temporality, short term labour contracts that accounted for more than $33 \%$ of labour contracts according to official statistics and to more than $50 \%$ according to other estimates $^{2}$ ) that decreased internal demand. The economy recovered a little due to four devaluations between 1992-94, increasing labour precariousness and the beginning of the building bubble. In 2000 unemployment was 20,4\% and in 2004 12,2\%. But to participate in the eurozone because of the Treaty of Maastricht another adjustment program was established and, without devaluation, competitiveness (internal and external) became more difficult. Nevertheless the euro permitted to keep a greater external trade deficit. In front of the problems of this model, capitals looked for non tradable sectors where competition was not relevant (building industry, commercial big areas) or oligopolic sectors being privatized (energy, communications) or financial speculation. On the side of demand, the willingness to reach the 'European level of consumption' was maintained and even increased through cheap credit, especially to buy apartments and the building industry boom was established.

2 "Del pleno empleo a la plena precariedad". Report from Seminario de Economía Crítica TAIFA, n. ${ }^{\circ}$ 3, Nov. 2006. 
During the period from 2000-2007, the Spanish economy was booming. Alongside the "Irish Tiger", the Spanish economy grew fast; it was admired for its liberalization processes, its new openness to international markets, with new emerging global players such as Telefonica, Ferrovial or Banco Santander. Obama's Transport Secretary visited Spain to check on the impressive new high speed train lines. Unemployment in 2007 was at the lowest since democracy even after absorbing more than 4 million economic immigrants in a decade. The housing market was highly dynamic and prices surged. After advancing Italy in GDP per capita terms in 2007, the president of the government, J.L Rodriguez Zapatero was feeling so confident that announced that in few years time, Spain will overpass France. Spain was pushing hard since Aznar administration to be recognised as an economic power and lobbying to enter in G8. Again Spain had an 'Armada Invencible' (or Spanish Armada). This time, composed by business men, financiers and investors.

However, despite a 'decent' average figures for income per capita (see Figure 1.3), an important income increase for most of the population and a very significant improvement in their qualitative ways of living - moving from a mainly rural and poor country to a industrialising and urbanised country -, the social picture is not so favourable, as can be seen in Figure 1.4. and Tables 1 to 4.

3 The Spanish Armada (or 'Armada Invencible' as it is named in Spanish) was the Spanish fleet that sailed against England in 1588. Despite the name, Spanish Armada was defeated. 
FIGURE 1.3.- GDP per head, Spain and EU-15 (1971-2010)

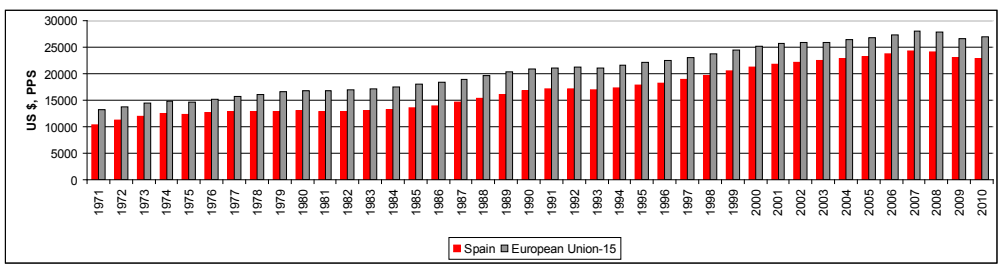

Source: Own elaboration based on OECD, 2011.

Real wages have increased very little since integration in the EEC (except at the beginning of the nineties), and both wages and share of wages have always increased at smaller percentages than in the EU-15; moreover, the share of wages in GDP has decreased during the whole period at Spain (See Figure 1.4.) as it has happened in the EU.

FIGURE 1.4. - Wages, gross operating surplus and taxes as GDP percent, Spain

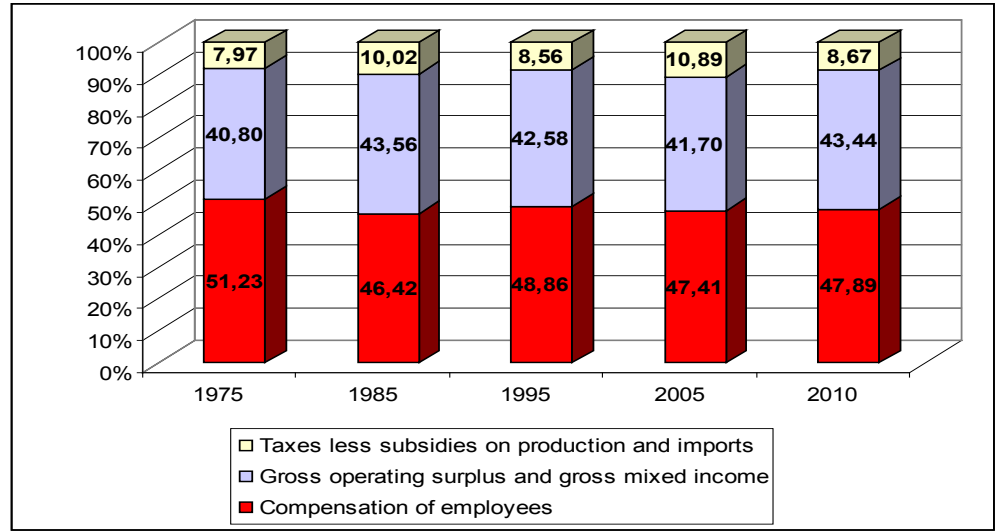

Source: Own elaboration based on OECD, 2011.

Indeed, it can be observed how social services are less satisfactory. Education, health, and other social elements are poorly provided for and expenditure on them is well below 
that of many other European countries (Table 1.1). These low levels have their base in the inheritance of the dictatorship and the relative gap in the social rights due to it. This shortfall (though declining) continued when Spain joined the EU, as well because fiscal pressure has been considerably lower than in the Union (Table 1.2).

TABLE 1.1. - Social benefits other than social transfers in kind (\% GDP)

\begin{tabular}{|l|l|r|r|r|r|}
\hline & 1990 & 1995 & 2000 & 2005 & 2009 \\
\hline European Union (27 countries) & $:$ & $:$ & $:$ & 19.8 & 21.8 \\
\hline European Union (15 countries) & $:$ & 20.9 & 19.4 & 20 & 22.2 \\
\hline Germany & $:$ & 25 & 25.8 & 26.6 & 26.7 \\
\hline Spain & $:$ & 15.7 & 14.3 & 14.2 & 17.5 \\
\hline France & $:$ & 22.8 & 22.1 & 23.4 & 25.4 \\
\hline Italy & 17.6 & 18.2 & 18.7 & 19.8 & 22.1 \\
\hline Finland & 15.7 & 23.3 & 17.8 & 18.7 & 20.9 \\
\hline Sweden & $:$ & 22.2 & 19.5 & 19.7 & 20 \\
\hline
\end{tabular}

Source: Eurostat, 2011 (no data found for Spain before 1990).

TABLE I.2. - Fiscal pressure (\% GDP)

\begin{tabular}{|l|l|l|r|r|r|r|}
\hline & 1985 & 1990 & 1995 & 2000 & 2005 & 2009 \\
\hline $\begin{array}{l}\text { European Union } \\
(27 \text { countries })\end{array}$ & $:$ & $:$ & 40.8 & 41.7 & 40.4 & 39.8 \\
\hline $\begin{array}{l}\text { European Union } \\
(15 \text { countries })\end{array}$ & $:$ & $:$ & 41 & 42.2 & 40.8 & 40.3 \\
\hline Germany & $:$ & $:$ & 41.3 & 43.3 & 40.2 & 41.1 \\
\hline Spain & $:$ & $:$ & 33.6 & 34.8 & 36.4 & 31.3 \\
\hline France & 44.5 & 43.4 & 44.5 & 45.9 & 45.4 & 43.5 \\
\hline Italy & 47.1 & 49.7 & 38 & 42.1 & 40.7 & 43.4 \\
\hline Finland & 42.2 & 45.2 & 46.3 & 47.4 & 44.1 & 43.3 \\
\hline Sweden & $:$ & $:$ & 48.5 & 52.1 & 49.3 & 47.4 \\
\hline
\end{tabular}

Source: Eurostat, 2011. 
Looking at the overall distribution of income, we can observe that is more unequal and the risk of poverty higher than the rest of EU15 (Table 1.3 and Table 1.4). In other words, we find a rather 'correct' economic development with a social development that lags far behind, no doubt as the inheritance of many years of dictatorship and the maintenance of the conservative powers and policies since them.

TABLE 1.3. - Income distribution. Gini index ${ }^{4}$

\begin{tabular}{|l|c|c|c|c|}
\hline & 1995 & 2000 & 2005 & 2009 \\
\hline EU-15 & 31 & 29 & 29.9 & 30.3 \\
\hline Germany & 29 & 25 & 26.1 & 29.1 \\
\hline Spain & 34 & 32 & 31.8 & 32.3 \\
\hline France & 29 & 28 & 27.7 & 29.8 \\
\hline Finland & & 24 & 26 & 25.9 \\
\hline Sweden & & & 23.4 & 24.8 \\
\hline
\end{tabular}

Source: Eurostat, 2011.

${ }^{4}$ It is difficult to find Gini index before 1990 but an article in Información Comercial Española asserts that since the beginning of the nineties, registered economic growth and increase in employment did not lead to a reduction of inequality, breaking then the trend towards it during 1973 to 1991. According to that article the causes of that significant change may have been the increase in jobs with low wages, austerity in wages and inefficiency of redistributive policies. (Ayala, L. y Sastre, M., 2007, "Políticas redistributivas y desigualdad", Información Comercial Española, n. $\left.{ }^{\circ} 837\right)$. 
TABLE 1.4. - Risk of poverty or social exclusion. ( $\%$ of the population)

\begin{tabular}{|l|r|r|r|r|r|r|}
\hline & 2004 & \multicolumn{1}{|c|}{2005} & \multicolumn{1}{c|}{2006} & \multicolumn{1}{c|}{2007} & \multicolumn{1}{c|}{2008} & \multicolumn{1}{c|}{2009} \\
\hline EU-15 & $:$ & 21.5 & 21.8 & 21.7 & 21.5 & 21.1 \\
\hline Germany & $:$ & 18.4 & 20.2 & 20.6 & 20.1 & 20 \\
\hline Spain & 24.4 & 23.4 & 23.3 & 23.1 & 22.9 & 23.4 \\
\hline France & 19.8 & 18.9 & 18.8 & 19 & 18.6 & 18.4 \\
\hline Italy & 26.4 & 25 & 25.9 & 26.1 & 25.3 & 24.7 \\
\hline Finland & 17.2 & 17.2 & 17.2 & 17.4 & 17.4 & 16.9 \\
\hline Sweden & 16.9 & 14.4 & 16.3 & 13.9 & 14.9 & 15.9 \\
\hline
\end{tabular}

Source: Eurostat, 2011 (no data found before 2003).

Yet, as capitalism is crisis ridden, sooner or later, the contradictions of capital will emerge and explode, bringing a period of strong restructuring. When the world crisis arrived at Spain all that new economic power melted in the air, growth vanished and Spain became one of the European countries more affected by the global downturn. Again, the Armada Invencible was beaten.

A very brief account of that evolution is what we intend to present in this paper, arguing that the rise and fall of the so-called "Spanish economic miracle", was based on very thin and unstable foundations. These foundations can be explained through how the Spanish economy was inserted in the circuits of global capital in the last half a Century, and in particular, its evolution in the last 15 years. Thus, when the contradictions of capital at global scale emerged, the house of cards of the Spanish economy fell down.

The paper is organised as follows. First, prior to analyse the current crisis in Spain, we will briefly explain how Spain has been connected to the global and European circulation of capital, and how its particular form of productive integration 
has brought the seeds for the unleashing of a major crisis in the context of the global financial turmoil. Secondly, we will analyse in more depth some of the determinants of that crisis to then discuss its combination with the debt crisis. Finally, we will present some reflections in the frame of the EU on the short and medium term scenario for Spain.

\section{Economic integration and the European periphery}

\subsection{Spain in the European Economy}

European economic integration embodies countries with very different productive models and varied competitive levels. Industrial specialization of the economies of the European periphery has been mainly based on keeping competitiveness by having low costs, mainly labour costs, thus, implying productive process of lower added value, second rate technology and high weight of little qualified labour. This has been the industrialization model of Spain.

European integration during the last decades has taken place in a context of globalization of capital with important changes in international and global redistribution of production and labour competitiveness. In this process, European investment and industry have been relocated to countries like China, India, and particularly to Eastern Europe. The previous advantages of the European periphery of low labour costs and legal permissiveness were losing competitive strength in front of the new members from Europe, more specifically, the relocation of European investment flows in the process of eastward enlargement of the European Union. Its relocation had clear losers for the other peripheral countries, including Spain. In this sense, the Spanish economy, along with other economies on the periphery of Europe as Greece and Portu- 
gal, have lost weight in the relative advantages for trade and in the attraction of international foreign direct investment (FDI) with respect particularly to Asia and Eastern Europe. This is a key factor in the process of deindustralization and degradation of the accounts of the external sector of the Spanish economy that has been progressively losing weight in international trade, and especially in the European one.

Competition of the Central economies in the context of the European Union and, especially, from the creation of EMU, has made more difficult, along with other factors (educational levels, etc.) the transformation of the productive structure towards higher technological content and greater value-added sectors. The weight of the sectors of advanced technology inside the Spanish production structure rose from 6.4 per cent of the industrial GVA in 1986 to 7.4 per cent in 1995, to decrease back to 6.5\% in 2007 (and thus, much less than the weight of these sectors in the EU-25 = 11.8\%). The external competitiveness of those sectors has also been eroded: cover rate of the most advanced industrial sectors has declined from 51.8\% in 1995 to 40\% in 2008 (Myro and Gandoy, 2009). Furthermore, there are the most advanced industrial sectors, which, in relative terms are being more affected by relocations (Myro and Fernández-Otheo, 2004).

A reverse process happened in central countries such as Germany and The Netherlands, where their specialization in industrial sectors and services of high-tech and its privileged competitive situation in the European and global space has allowed them to maintain a constant current surplus thanks, in large part, to demand from the European periphery. Meanwhile the periphery has to survive with low value added industries and increasing debts, in particular external debt.

The model of trade relations in the euro area presents a composition of peripheral demands dominated by products manufactured abroad, the larger part in the central European 
zone. The peripheral countries have provided with a demand that has benefited the core economies on the continent. The indirect effects of final demand from countries such as Spain on the export of Germany should be considered in this process. Even important effects of drag (backward linkage) final demand manifested through sales of intermediate products and machinery of high technology to developing countries like China which is used to produce the final goods consumed ultimately by Spain. The economic space of the EU has been changing from a situation where the periphery has moved from being the precarious industry of Europe to becoming places aimed at ensuring an abundant demand fed with debt for the production of the central countries, the latter being at the same time the main suppliers of credit to the peripheral countries that buy the products.

The result of these very different dynamics in the European Union has been a trade imbalance and a growing divergence in competitiveness between the centre and the periphery. It is true that the levels of per capita income have starred a slight convergence during part of the first decade of the 21st century, however differences in competitiveness and production models have increased, resulting in a growing instability as a reflection of the profound imbalances in the euro zone.

Therefore, a feature of the economies of the Eurozone is the confluence of countries with continuous current-account deficits on the one hand, geographically located in the periphery, and on the other hand, countries located primarily in the central area, with surpluses on their current balance, especially Germany. Both dynamics are negatively correlated, in the sense that the deficits of the first are the surpluses of the latter, a situation that has resulted in a structural divergence between both groups of countries. 


\section{FIgURE 2.1.- Surplus/deficits in current account as percentage of GDP}

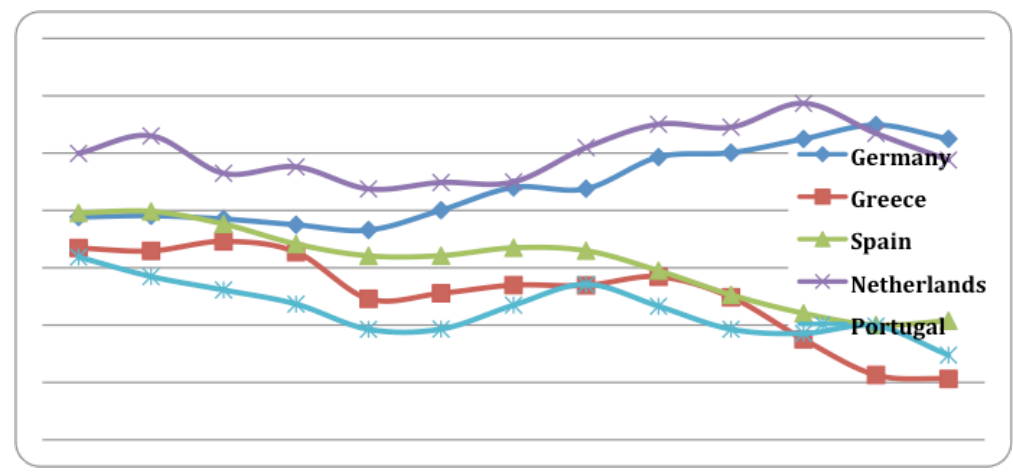

Source: Own elaboration with Eurostat data.

As it can be seen in Figure 2.1 that these deficits consolidated and increased highly with the Monetary Union and the facilities that it generated in the peripheral demands.

But demand has to be financed and it has been in a high part financed by external debt, by resources of various kinds. Especially because the Spanish economy has gone in the last decade from being a net recipient of FDI to a net emitter. This is due both to a stagnation of direct investment inflows and an outstanding increase in investments of Spanish companies abroad.

The external debt of the peripheral countries of Europe has been financed mostly by financial institutions of the central countries, funds which originate in the trade surpluses we have commented upon. Thus a round circle was established: the banks of the central countries provided with the credits to the periphery countries for these to buy the goods produced in the central countries.

In Spain, as in the rest of the periphery, most of these resources have been exclusively financial in nature, where the 
portfolio investments and bank loans have become the main source of funding for the last decade. According to the Bank of Spain, portfolio investments doubled its weight in GDP in the 4 years prior to the crisis, from $50 \%$ in 2003 to $104 \%$ in 2007, displacing the importance of foreign direct investment (FDI). This fact is explained on the one hand by the change in the form of funding such financing in a context of high financial innovation, and on the other hand by the important decrease in received FDI.

Before the crisis, Spain had one of highest external debt as percentage of its GDP among the most important countries in the world - in 2006 and 2007 current account deficit was $9 \%$ and $10 \%$ of GDP, while it was the second in absolute value, only behind the United States. It has decreased because of the crisis to 6\% in 2009 and $4.7 \%$ in 2010.

Without downplaying the competitive decline of the Spanish economy, the adoption of the euro has been key in this process since it allowed for many years a high external deficit with nobody in the decision making realm caring for an infeasible level of external debt. Besides facilitating trade the less competitive countries lost their main strategy for external imbalances (devaluation) and were submitted to an institution as the ECB mainly caring for the central counties interests. Sharing the same currency led to the abandonment of the 'risk premium' (prima de riesgo) for the Spanish debt for our main creditors. This in a context of fall of real and constant interest rates with constant innovation and financial deregulation increased private indebtedness disguising the feet of clay of the Spanish economic growth and the imbalances of the eurozone. 


\subsection{The role of the European Union in the integration of the Spanish Economy}

We all know the role of the EU in all this process. In the first period after accession (1986, the year of the Single Market) the fact that Spain belonged to the EEC gave security to European investors more interested in buying existing industries than expanding or improving the productive capacity, while many Spanish entrepreneurs took the opportunity to sell their industries. The Single Market also facilitated as we say above that Spain became a good market for the products of the central countries of the Union (including technology and technological knowledge). An important number of small industries disappeared and the productive tissue of the country already weakened by the crisis of the seventies approached a dual structure: few modern corporations and many small traditional ones struggling to absorb advanced technology in order to produce competitively for the internal market and export. A high external deficit developed that could only be solved with four devaluations in two years (92-94) but of course, after the euro no such instrument could be relied upon.

The Maastricht Treaty (1992) and its conditions together with the strong will of the Spanish Government to be among the first group of countries in EMU led to a though adjustment program during the first part of the nineties. The macroeconomic conditions for taking part of the eurozone were fulfilled and the country became a full member of it but the economy did not recover before 1995. In the realm of production the car industry and tourism expanded, but competitiveness lagged behind and the big increase in imports and the smaller if positive development of exports led to the corresponding high deficit in current account. However, since belonging to the Union has permitted a high external deficit 
no preoccupation due to it appeared even among the main economists of the country.

We are proud Europeans with the new currency now, but except for the peasants no many improvements for the population came from 'Europe' despite that the country has been a net recipient of European funds for around 1-1.5\% of its GDP since accession to 2013 when Spain will start to satisfy a net contribution to the Union.

But no policies exist at the Union to improve the productive structure of the member countries. Well until the second half of the nineties the structural funds (FSE, FEDER and the development part of the CAP) were but a very small proportion of the total budget of the Community. The proportion increased in the late nineties - together with the Cohesion Fund they account for more than a third of the total budget of the EU - but the total budget has not increased but decreased and we all know the poor funds that it allows for. Besides, those funds were mainly directed to agriculture and regional development in some sort of 'poor region and agriculture assistance'. Moreover, a proportion of these funds coming from the Union have been mainly utilized to build infrastructures (some of them absurd, as the many kilometres of High Speed Trains [AVE] built, we are the country in the world with more kilometres of AVE except China, or of motorways or many municipal sports camps), whereas the European Social Fund (ESF) was dedicated to cater for the many courses (same of them fake) that were given to unemployed workers by the Unions and Employer Associations ${ }^{5}$.

${ }^{5}$ These courses were a way to finance the Unions and Employers Associations and the official objective of improving the qualification of workers, especially unemployed ones, was mainly the reason adduced to distribute the funds. Most of the courses were a requisite for the unemployed to get the corresponding subsidy with no interest in quality and 
Imbued as it is that the markets are the best instrument for economic development the Community has never had any programs to balance or improve the nucleus of productive capacity of the member countries ${ }^{6}$. The other way round, in fact public subsidies to enterprises are forbidden. The policies of the Union have led to the development of the central parts of it, remember the 'golden banana'. Nevertheless most of the population and especially all those in any position of leadership or power considered that being members of the EU was full of advantages.

\section{The 'domestic' pattern of growth: housing bubble and 'national champions'}

Summing up, during the 1990s the Spanish economy was heavily dependent on foreign capital that had already started to move out towards Eastern Europe, Asia and North Africa. Locally owned capital, in general terms, remained uncompetitive internationally. The economy was driven by internal demand, tourism and thanks to the EU Structural and Cohesion Funds, investment in infrastructures was possible beyond the capacity of the Spanish state. Yet, in the late 1990s and early 2000s, this receipt for failure was transformed into the "Spanish Economic Miracle". This so-called miracle was sustained by two major set of events. On the one hand, and the most prominent, the housing bubble; on the other hand, and though more discursively than effectively, the internationalisation of a few Spanish-based holdings created from the privatisation of state companies and monopolies.

very little even in assistance and some instance of non existent registered courses have been found.

${ }^{6}$ I have made the same remark often in the yearly meetings of the Euromemorandum group. 


\subsection{The rise of the housing bubble}

After the year 2000 and following the world trend, liquidity was abundant and the rates of interest low. A number of elements existed and developed that led to an enormous expansion of the construction industry all over the world. ${ }^{7}$ In Spain, that expansion was spectacular. The reasons behind these developments are several. The most important among them were:

First, there was a lack of profitability in the manufacturing and service economy. As mentioned before, the Spanish economy was weak, with low productivity. Its competitiveness depended on reductions of real wages and not on innovation. Spanish manufacturing was facing strong competition; also, the first 90s witnessed a new austerity program and diminishing of growth while for the late nineties there was the enlargement of the EU and the rise of China. Therefore a strong reduction of profit margins in the real part of the economy and the moving of funds to other undertakings.

Second, there existed already an important building industry. In Spain, since the Franco era have existed a small number of important construction industries (particularly civil engineering ones) that had grown at the shadow of big public works economic, through favours from the State and even and political corruption. At present, $5 \mathrm{Spa}-$ nish enterprises are among the 50 greatest enterprises in the world and most of them originated during Franco period.

7 Although the trend was common all over the world (Harvey, 2010; Aalbers, 2011) it is also true that, for instance, many countries in Europe maintained sustainable growth in the housing market (e.g. Belgium, Switzerland, Germany (CHISLETT, 2009). Yet, it is true also that investors and financial institutions from those countries invested heavily in the housing bubble elsewhere (as in Spain). Also, during the 2000s, and particularly after the dot.com bubble busted, the participation of real estate assets in the balances of companies everywhere double in general terms (FT, 2006). 
Third, during the second part of the nineties important deregulation measures and a very permissive legislation for building and urbanisation took place. Land use was liberalised, and critically, a new category of land was created: "suelo urbanizable" (developable land). That is rustic land that can be categorised as potentially site for construction. Moreover, one of the most important sources of income for municipalities (the tax on economic activities, IAE in its Spanish acronym) comes from the permits for building. Thus the activity of municipalities requires and construction permits an increased source of funds for local authorities and more relaxed financing procedures.

Fourth, a situation of abundant and cheap credit both the world over and also in Spain, that provided credit with good terms, on the one hand to the building and real estate industry and for apparently cheap mortgages for families, on the other. In contrast to USA for instance, it is worth mentioning that almost the half of mortgages given in Spain during that period were given to developers. It was not uncommon that developers started a promotion based only with $20 \%$ of own sources, and the rest leveraged through mortgages.

Fifth, an historically degraded dwelling stock, cheap credit and new developments meant a longing for better homes of the Spanish population that devoted their newly found incomes mainly to the provision of better housing.

Finally, also a fair number of European visitors decided to buy an apartment or a house in Spain, especially in the sunny areas of the East and the South, were many English and German pensioners found a good climate and cheap cost of living in relation with their pensions. Also, in the last period of the boom immigrants who had a job, mainly in the building industry, started to buy apartments.

In this scenario an entrepreneurial class developed rapidly seeking high short term profits - many times, housing development changed ownership several times even before 
the beginning of works -, and prepared to pressure public authorities to obtain very favourable terms for urbanisation of rural lands and building.

Many enterprises expanded their previous trade or started building apartments ${ }^{8}$ which were sold very easily with the help of 'favourable' terms of credits to buying them as well as fiscal benefits for buying them. The prices of apartments started rising very rapidly and strongly but credits were awarded for longer periods - mortgages changed from 12-15 years to $30-40$ years - and the rate of interest was low, therefore many working people could afford a new house ${ }^{9}$. The idea that the value of houses could only go up was well established and the very wide offers of credit by the banks and the Savings bank led people to engage themselves in apartments at thirty of forty years mortgage. People kept buying thinking that they could always sell the house if they changed their mind or found themselves in difficulties. Building followed a hectic rhythm. The big building enterprises led the way but they were followed by every small entrepreneur and workers of the building trades that could buy a piece of land started building houses. So much so that from 2004 more than 500,000 apartments or houses were built per year, and in 2005 more than the ones built by France, Germany and the United Kingdom taken together (Observatorio de Energía y Sostenibilidad en España, 2008) creating a housing stock of 23 million in a country of 45 million inhabitants) (Chislett, 2008). Note

${ }^{8}$ Most of the Spanish population living in cities and medium sized towns live in apartments. Houses are only for people living in rural villages and at present for secondary residences.

9 It has to be taken into account that most of the people buying a house or apartment calculate mainly if they can afford the monthly instalment of the mortgage, more than the total price of the house. Cheap credit and long mortgage periods make possible for modest income to buy apartments even if the total price is unbearable. 
that this means using a very great share of the funds for investment in the country. Foreign investment in real estate increased sensibly up to 7,000 million euro. Building and selling house became the big business of the country accounting for $15.7 \%$ of Gross Value added and $23.4 \%$ of employment.

This led to a period of prosperity, because building is labour intensive and with jobs of low qualification and therefore there was plenty employment and wages were not bad in comparison with other sectors. So much so that Spain was able to accept a big contingent of immigrants that went to work directly in the building industry (the women went to work to care for the old people and the children of the Spanish families).

Not many efforts were required to gear the economy. The boom sector in the building industry coincided with a good conjecture in the rich world too. Export of cars, the building and real estate industry advanced at full swing, tourism was the only sector presenting some problems because its old buildings and structures together with overcrowding led to decreasing competitiveness in front of new countries. But from 2003 to 2007 Spain experienced a period of high prosperity. By 2004, 1.8 million new jobs had been created, unemployment had fallen to a record low of 8.1 percent of the active workforce, and 60 percent of all new jobs in Europe were created in Spain (Royo, 2009). It is noteworthy that, when most governments in the EU were struggling to keep their fiscal deficits in check, Spain enjoyed three years of consecutive surplus between 2005 and 2007. Building, automobile and tourism constituted the trilogy upon which the prosperity was based. In spite of weak increases in wages even decreasing ones in medium term terms - and the strong temporality in employment (33\% of labour worked in temporary terms according to official statistics), the abundant and easy credit offered by the financial institutions that tried to 
pursue people to use extra money permitted demand to be abundant and fluent.

Financial institutions demanded credits abroad in order to increase their lending to the domestic building industry, what together with the permanently increasing trade deficit (as it is mentioned in 2.1) increased the external debt of Spanish economy ${ }^{10}$.

All the prosperity came abruptly to an end. At the end of 2006 the big building industries were already giving signs that the building boom could not continue given the extremely high price of houses. But in the second semester of 2007 with the financial crisis of the United States and the freezing of credit the world over the whole house of cards came down. The real economy was operating fictitiously for many years - real wages were not increasing and productive activity was concentrating in very few sectors - and demand was being financed and sustained with credit; when it froze not only house buying and building stopped but overall consumption came down rapidly. And the many and serious weaknesses of the Spanish development model of the $21^{\text {st }}$ century came fully into the open.

\subsection{The new national champions in context}

Another 'domestic' aspect of the economic development of Spanish economy is the existence of few powerful firms in strategic sectors, popularly called the 'national champions'.

${ }^{10}$ Besides the traditional high trade deficit foreign investment in Spain implied obviously returns for that capital. While foreign in-flows were increasing the net balance was positive, but when foreign investment diminished, the returns for past inflows of capital started to represent a substantial outflow in the Balance of payments. 
The capitalist development of Spain has also meant that a few big Spanish holdings have been developed, some of them previously public industries that were privatised during the 90s. Indeed, the concentration of capital after the privatization of public companies gives them a oligopolistic - if not monopolistic in some cases - position in the domestic market. This situation allowed them to have a solid base for succeeding as national champions and internationalise their activities. In neoliberal discourses and strategies in Spain, they have played a fundamental ideological role in selling internally the Spanish Miracle. Yet, at present a few firms and banks are significant in the global economy: Repsol (petroleum), Sacyr (building), Aguas de Barcelona (itself owned by Suez-EDF, but highly active in Latin America), Telefónica, Banco Santander \& Banco Bilbao Vizcaya Argentaria (BBVA) and some others such as Ferrovial (civil engineering, utilities), Abertis (utilities) Zara and Mango (fashion). They have added a complete new dimension to the world power of Spanish enterprises. At the beginning these holdings tended to develop in Latin America (as if recovering the traditional ties between these territories), but at present their power permits them to expand the world over. And most of the times, their expansion came heavily leveraged (Economist, 2007). Obviously that implies that substantial investments have gone to foreign lands increasing the external deficit at least in the short run.

Gradually the productive structure of the country at the beginning of the XXI Century consists of a few great firms owned by foreign transnational holdings, another set of great autochthonous firms, themselves transnationals operating in other countries, very few really competitive industries in advanced technology (see Box 1) - and a myriad of small firms working either for the first ones or for the internal market. The weakness of internal demand and the pressure of economic facts has also led to the development of quite a number 
of firms dedicated to exports, which are increasing. However, the country suffers a permanent foreign dependency on technology and knowledge. Even the sectors making for prosperity were sectors of a medium level of technology, like the building and car industry.

Box 1. - Some technologically advanced industries in Spain. The country has a significant industry in hemoderivatives (Grifols, third in the world), telecommunications (Telefonica, first in Europe and third in the world), tridimensional radars, fly simulators, control of air traffic, telecommunications satellites (Indra and GMV) satellite communications and aeronautics (Hispasat). Spain counts with the greatest firm in the world in transport infrastructure (Ferrovial-Cintra) and among the 10 greatest, five are Spanish, REPSOL is leader in energy, and in renewable energies three Spanish firms are important (Gamesa, Abengoa, Iberdrola). Even in machine-tools it is important with Germany as its more important client. (Taken from El País, "Negocios", 24-7-2011)

In sum, in a context of great expansion of world trade the Spanish productive system shows the weakness of its productive specialisation, where the most competitive sectors have been losing weight in front of other activities leading its growth. Spain has had no solid and permanent productive development but has been surviving through a model of low productivity, low wages, high labour precariousness and enormous ecological deterioration. With a few strategic modern sectors (automobile, chemistry and agro-industry ${ }^{11}$ ) at the hands of foreign capital and very few advanced technological sectors, with the main chunk of enterprises very small and at the hands of native entrepreneurs only used to very tra-

${ }^{11}$ Agro-industry was foreign owned for most of the eighties and nineties but it was re-bought by Spanish capital during the last decade. 
ditional managing ways, mainly directed to exert pressure and if in difficulty dismiss workers. In fact the traditional poverty of the country has only been disguised for a period - 60s to 90 s - with a good global conjuncture, foreign initiatives, cheap wages and external credit to sell cheap and low productivity products; it has been functional to the central countries of the continent to buy their technological and high value added products through credit. Only a few firms have become powerful global undertakings and other few ones of advanced technology have developed but they are from being enough to drive the country behind them. The country does not have enough solidly grounded productive undertakings and general structure. The continuous surge of the real estate industry hidden the weaknesses of the Spanish productive system but the crisis has exposed the poor base of Spanish economy dynamics. A heavily indebted country, with very few advanced sectors, a lack of technological development and a hypertrophied building and real estate sector. A poor recipe for further developments.

\section{The crises, indebtedness and adjustment policies}

\subsection{The first impacts, 2007-2009}

When the financial crisis started in the United States and expanded trough the world the Spanish authorities and even the financial sector reacted with a rather optimistic outlook. Spanish banks did not seem to be significantly involved in the American mortgage problems and due to a bank crisis Spain had suffered in the eighties Spanish banks had tighter regulations and reserves than the rest of western banks. The outlook did not seem that grim. In fact, the Spanish government kept maintaining that regarding the Spanish Economy, the finan- 
cial turmoil only implied a soft landing. This was the official position until spring $2008^{12}$. However, after the general elections in March 2008, a weakened socialist party (PSOE) kept the power and the government had to face the crisis. The government (and the main economic agents) understood the problem for the Spanish economy as a temporary external shock. There were no domestic fundamentals, not even the hypertrophied real estate sector or the low productivity of the local economy.

For two years, 2008-2009, the Socialist Spanish Government took a whole set of rather chaotic measures in principle trying to advert the worst consequences of the crisis. No permanent and coherent line of action could be observed but a whole variety of very diverse and even contradictory measures were taken ${ }^{13}$. The discourse to legitimate the measures was that the social rights of the population had to be maintained but in fact the measures were mostly in favour of financial and big industrial capital and anticipated in part the tougher measures that would be taken later. Indeed, measures to recover growth and create employment were weak and timid. They were mostly aimed at helping the financial industry which was under a lot of pressure from international markets and Spanish big fortunes. Yet, unemployment was already above $19 \%$ of the working population in 2009 . There was very poor support for the people more heavily hurt by the crisis, as unemployed or evicted families due to lack of payment of mortgage that were increasing rapidly.

12 There were general elections in March 2008 and the willingness to deny the crisis until alter the elections was also an important element in the denial.

${ }^{13}$ For a detailed analysis of these measures, see 'El rescate de los poderosos', Report from Seminario de economia Crítica TAIFA, n. ${ }^{\circ} 7$. 
But this was only the beginning. The situation kept deteriorating. Growth, investment and consumption collapsed, unemployment increased and many firms asked their workers to accept lower wages in exchange for not increasing the dismissals, and workers accepted. Temporary jobs increased (more than 94\% of new contracts were temporary). The two big unions of the country (CC.OO and UGT) were totally amenable to the wishes of the government and kept signing agreements with it. Their only aim seemed to achieve better lay-off compensations for the workers that were made redundant. Spanish workers seemed willing to accept the new situation and, with few exceptions, no resistance appeared.

In sum, during 2008-2009, the working class was already heavily suffering from the crisis and from the measures taken to face it. Yet, they did not to react. The idea that the (internationally driven) crisis made unemployment, lower wages and precariousness of work inevitable seemed to have been assumed by the population.

\subsection{The debt crisis and policy reforms}

During this period 2008-2010 deficit and debt of the Spanish economy increased rapidly and its dependence on external credit became clear (see Tables 4.2.1 and 4.2.2.). The credit that was at the basis of the 'prosperity' and growth of the Spanish economy of the first decade of the century came to the centre of the stage and showed the very precarious nature of that growth and the very vulnerable situation of the Spanish economy. 
TABle 4.2.1. - Public deficit (as \% GDP), some European countries, 1998-2010

\begin{tabular}{|l|r|r|r|r|r|r|r|r|r|}
\hline & EU(27) & Euro area & Germany & Greece & Spain & France & Italy & Finland & Sweden \\
\hline 1998 & $-1,9$ & $-2,3$ & $-2,2$ & $\mathbf{1}$ & $\mathbf{- 3 , 2}$ & $-2,6$ & $-2,8$ & 1,5 & 0,7 \\
\hline 1999 & -1 & $-1,4$ & $-1,5$ & $\mathbf{1}$ & $\mathbf{- 1 , 4}$ & $-1,8$ & $-1,7$ & 1,6 & 0,9 \\
\hline 2000 & 0,6 & 0 & 1,3 & $-3,7$ & $\mathbf{- 1}$ & $-1,5$ & $-0,8$ & 6,8 & 3,6 \\
\hline 2001 & $-1,4$ & $-1,9$ & $-2,8$ & $-4,5$ & $\mathbf{- 0 , 6}$ & $-1,5$ & $-3,1$ & 5 & 1,5 \\
\hline 2002 & $-2,5$ & $-2,6$ & $-3,7$ & $-4,8$ & $\mathbf{- 0 , 5}$ & $-3,1$ & $-2,9$ & 4 & $-1,3$ \\
\hline 2003 & $-3,1$ & $-3,1$ & -4 & $-5,6$ & $\mathbf{- 0 , 2}$ & $-4,1$ & $-3,5$ & 2,4 & -1 \\
\hline 2004 & $-2,9$ & $-2,9$ & $-3,8$ & $-7,5$ & $\mathbf{- 0 , 3}$ & $-3,6$ & $-3,5$ & 2,3 & 0,6 \\
\hline 2005 & $-2,5$ & $-2,5$ & $-3,3$ & $-5,2$ & $\mathbf{1}$ & $-2,9$ & $-4,3$ & 2,7 & 2,2 \\
\hline 2006 & $-1,5$ & $-1,4$ & $-1,6$ & $-5,7$ & $\mathbf{2}$ & $-2,3$ & $-3,4$ & 4 & 2,3 \\
\hline 2007 & $-0,9$ & $-0,7$ & 0,3 & $-6,4$ & $\mathbf{1 , 9}$ & $-2,7$ & $-1,5$ & 5,2 & 3,6 \\
\hline 2008 & $-2,4$ & -2 & 0,1 & $-9,8$ & $\mathbf{- 4 , 2}$ & $-3,3$ & $-2,7$ & 4,2 & 2,2 \\
\hline 2009 & $-6,8$ & $-6,3$ & -3 & $-15,4$ & $\mathbf{- 1 1 , 1}$ & $-7,5$ & $-5,4$ & $-2,6$ & $-0,7$ \\
\hline 2010 & $-6,4$ & -6 & $-3,3$ & $-10,5$ & $\mathbf{- 9 , 2}$ & -7 & $-4,6$ & $-2,5$ & 0 \\
\hline
\end{tabular}

Source: Eurostat (2011).

Table 4.2.2. - Public debt (as \% GDP), some European countries, 1998-2010

\begin{tabular}{|l|r|r|r|r|r|r|r|r|}
\hline & EU (27) & Euro area & Germany & Greece & Spain & France & Italy & Finland \\
\hline 1998 & $:$ & 72.9 & 60.3 & & $\mathbf{6 4 . 1}$ & 59,4 & 114.9 & 48.4 \\
\hline 1999 & 65.7 & 71.7 & 60.9 & 94,0 & $\mathbf{6 2 . 3}$ & 58,9 & 113.7 & 45.7 \\
\hline 2000 & 61.9 & 69.2 & 59.7 & 103,4 & $\mathbf{5 9 . 3}$ & 57,3 & 109.2 & 43.8 \\
\hline 2001 & 61 & 68.2 & 58.8 & 103,7 & $\mathbf{5 5 . 5}$ & 56,9 & 108.8 & 42.5 \\
\hline 2002 & 60.4 & 68 & 60.4 & 101,7 & $\mathbf{5 2 . 5}$ & 58,8 & 105.7 & 41.5 \\
\hline 2003 & 61.8 & 69.1 & 63.9 & 97,4 & $\mathbf{4 8 . 7}$ & 62,9 & 104.4 & 44.5 \\
\hline 2004 & 62.2 & 69.5 & 65.8 & 98,6 & $\mathbf{4 6 . 2}$ & 64,9 & 103.9 & 44.4 \\
\hline 2005 & 62.8 & 70.1 & 68 & 100,0 & $\mathbf{4 3 , 0}$ & 66,4 & 105.9 & 41.7 \\
\hline 2006 & 61.5 & 68.5 & 67.6 & 106,1 & $\mathbf{3 9 . 6}$ & 63,7 & 106.6 & 39.7 \\
\hline 2007 & 59 & 66.3 & 64.9 & 105,4 & $\mathbf{3 6 . 1}$ & 63,9 & 103.6 & 35.2 \\
\hline 2008 & 62.3 & 70 & 66.3 & 110,7 & $\mathbf{3 9 . 8}$ & 67,7 & 106.3 & 34.1 \\
\hline 2009 & 74.4 & 79.4 & 73.5 & 127,1 & $\mathbf{5 3 . 3}$ & 78,3 & 116.1 & 43.8 \\
\hline 2010 & 80 & 85.3 & 83.2 & 142,8 & $\mathbf{6 0 . 1}$ & 81,7 & 119 & 48.4 \\
\hline
\end{tabular}

Source: Eurostat (2011). 
The high deficit was due on the side of expenditures to the generous help given to the financial sector as well as to the other programs to face the crisis, among then the very high expenditure due to unemployment subsidies; but also to the deterioration of the revenues, as in 2009 tax revenues decreased $17 \%$ because the lower economic activity. Since the eighties the fiscal system had been geared to diminish taxes to the rich, entrepreneurial benefits and of the financial system (especially investment and pension funds). The crisis deteriorated the financial situation of the government but the deterioration is also due to the political will to maintain and improve the fiscal system in favour of the richest: not only increase of taxes in profits of enterprises and returns to capital have been extremely low, if any, but taxation on Wealth and Inheritance have been eliminated, while Value Added Tax and others on consumption have increased.

But debt has to be classified: the Spanish public debt is low in comparison with other countries but private debt is high and especially external private debt due as we have already said both to the traditional deficit in current account and also to the increase in the financial debt of financial institutions (Banks and savings banks) that had demanded heavy credits abroad to be able to expand their credit operations with the construction and building industry internally. In 2009 it became clear that Spanish financial institutions had not been exposed to the USA subprime problems because they had plenty to worry about their own internal building and real estate operations.

As it can be seen in table 4.2.2 and 4.2.3 Spanish public debt is not that high, and stands well below most Eurozone countries. If Spain had only to care for its public debt it does not seem the problem will achieve such dimensions as it is estimated that even now, with all the increases in the 'country risk premium' that the evaluations of the rating agencies are 
inducing, the cost of interests on the debt is not more than $2.2 \%$ of GDP well below other previous periods.

\section{TABLE 4.2.3. - Spanish Debt 2009-2010 (Millions of euros)}

Total

Foreign debt Millions $€ \quad \%$ GDP $\quad$ Millions $€ \quad \%$ GDP $\begin{gathered}\% \text { foreign } \\ \text { debt }\end{gathered}$

\section{Public debt}

Spanish total public debt

66.48

351,966

33.12

20.19

Central government

539,597

50.78

n.a

n.a

n.a

Regions

114,279

10.75

n.a

n.a

n.a

Municipalities

35,380

3.33

n.a

n.a

n.a

Social Security

17,169

1.62

n.a

n.a

n.a

Private debt

\begin{tabular}{lrrrrr} 
Residential sector & $2,378,656$ & 223.85 & $1,391,581$ & 130,96 & 79,81 \\
$\quad$ Non financial societies & $1,476,546$ & 138.96 & $n . a$ & $n . a$ & $n . a$ \\
Households & 902,110 & 84.90 & $n . a$ & $n . a$ & $n . a$ \\
Financial entities & $1,127,688$ & 106.13 & $n . a$ & $n . a$ & $n . a$ \\
Total debt & $\mathbf{4 , 2 1 2 , 7 6 9}$ & $\mathbf{3 9 6}$ & $\mathbf{1 , 7 4 3 , 5 4 7}$ & $\mathbf{1 6 4}$ & $\mathbf{1 0 0}$ \\
\hline
\end{tabular}

Source: Own elaboration with data from Banco de España and other sources.

TABLE 4.2.4. - Public and foreign debt comparison

\begin{tabular}{|c|c|c|c|c|c|c|}
\hline \multicolumn{7}{|c|}{ Public debt as $\%$ of GDP } \\
\hline Japan & Italy & Euro Zone & France & Germany & EU Mean & Spain \\
\hline $200 \%$ & $114 \%$ & $84 \%$ & $76 \%$ & $73 \%$ & $73 \%$ & $66 \%$ \\
\hline \multicolumn{7}{|c|}{ Foreign debt as \% GDP } \\
\hline Ireland & UK & USA & Japan & & & Spain \\
\hline $1052 \%$ & $413 \%$ & $94 \%$ & $42 \%$ & & & $164 \%$ \\
\hline
\end{tabular}

Source: Own elaboration with data from Banco de España and other sources. 
It seems there is a deliberate confusion among the requirements that present the different types of debt and their finances. Spanish total debt reaches about $400 \%$ of GDP but public debt is about $60 \%$, and financed in its $52 \%$ by national banks, while external debt is $170 \%$ of GDP. Somewhere there is some collusion between public and private debt and their external parts. The problem seems to rest on the external private debt and not in the public debt. Therefore a question may be, why does the Spanish population have to respond to private debt (mainly banks and big enterprises), is it not possible to leave the debtors of private debt deal with their creditors and both with their financial problems? A relevant and interesting question even if might seem rather naif.

In any case, within this frame the question of the Spanish external debt takes the stage. Global financial markets and International public institutions - IMF and especially EU started compelling the Spanish government to comply the well-known adjustment programs and in 2010 an important change in policy took place. Already in January the Spanish Government started enacting some adjustment measures but in May 2010 the Government was compelled to approve a very tough austerity program: an important cut in the budget, 50,000 million euro for the next three years, ${ }^{14}$ that led among other things to a reduction of $5 \%$ on average in the wages of public employees, the freezing for one year of pensions, together with a reform of labour legislation (liberalisation) and a reform of public pensions (privatisation). And a total change in priorities in front of the crisis: all reference to growth or

${ }^{14}$ The importance of the cut may be assessed in rather crude calculations if it is compared with the amount of the measures against the crisis taken during the two previous years, that may be estimated in about 15,000 million euro for the next three years and 20,000 for the following 10 years, except for the support to financial capital that is not included in those figures. 
unemployment or the maintenance of social services was forgotten and the only objective of policy from then on became the reduction of public deficit and control of public debt. Zapatero was congratulated by Mrs. Merkel and Mr. Sarkozy by his resolve.

Since then many other measures to save in public expenditure are being continuously taken - diminishing or disappearance of many social subsidies and important cuts in public investment, expansion and new systems of privatisation to the last public enterprises that remain and a strong drive to stimulate private provision of social services, value added tax has been increased - and many others are announced. A decrease in the public deficit has been achieved in 2010 (it will decrease to 9,2\% of GDP) and more is estimated for 2011 (6,6\%).

The crisis went deepening as could be expected with these measures. Against the will and the expectations of the public authorities the signs of improvement were extremely weak, rather non-existent. With the building industry totally disrupted, unemployment reached very high figures, wages deteriorated and without credit demand lagged far behind the needs of industry leading to the closing of many small firms and to high unemployment figures. Exports maintained more or less their level and even increased due to the recovery of other European countries but were not enough to keep the economy growing.

The situation of the country in 2010-2011 is one of high unemployment, very weak demand, an important debt, especially external debt and a very weak productive system. Out of the three main sectors driving the economy during the boom: building, car industry and tourism, the first one is totally bankrupt, the second one presents serious problems and the third one is only maintaining itself 'thanks' to the political upheaval in the touristic countries of Northern Africa. Considering the question in depth the Spanish problem is not 
only an indebtedness problem but in the long run the really serious problem is the weakness of its productive system. The shortcomings of this model are evident and one of the stated aims of policy is that of 'changing the productive model' but this is more easily said than achieved. Trying to emulate Germany is already an 'old' model and moreover Spain does not have the investments, the technology, the qualifications of the labour force, and especially lacks the entrepreneurial and political leadership to achieve such an aim, more so in a period of a world crisis.

In 2011 the adjustment measures have continued but they have not avoided that Spain were included among the high debtor countries in 'danger' together with the other periphery countries of Greece, Ireland and Portugal. As is well known we are now a part of the 'irresponsible' countries of the Unión and submitted to increasingly severe adjustment programs and to the hectic measures imposed from the EU (Pact for the Euro and others). Adjustment becomes permanent in lines of really deep and tough neoliberal measures ${ }^{15}$.

The Government is trying to accomplish a double (impossible?) role: on the one hand they are insisting that we are not Greece or Portugal and, on the other it is arguing that in order to avoid being 'rescued' we have to accept the very tough measures that are being taken ${ }^{16}$. And they are tough indeed. One may wonder if it is worth to indulge into these measures to avoid being rescued, if there is any difference between the peripheral rescued countries and those that have not been rescued yet, as Spain.

15 It is dubious to classify these measures as neoliberal since they are tougher and deeper of what constituted the standard neoliberal measures, but they share the main lines of neoliberalism and therefore we shall use that name by lack of a better denomination.

${ }^{16}$ It may be though why we should be afraid of the rescue if the measures associated with it are already being taken. 
When writing those lines (middle August) we are subject to the new alarm about the deterioration of the country risk and the corresponding increase in Spanish (and as well Italy and France) risk premium, even if at the basis of these increases there are elements that have nothing to do with our economy as the increase in the alarm about a new world recession and the incapacity of European and world leaders to deal with it. If it was not that dramatic and hurting so many people it could be though the EU and the world economy are in the middle of a cabaret vodevil. And in this vodevil, the last chapter so far has been the announcement at the end of August by the President of the Spanish Government of changes in the Constitution to include in it the impossibility of incurring in budget deficits. With the support of the right wing opposition, this measure is meant to be approved very fast $-2^{\text {nd }}$ of September - , before the dissolution of the parliament on September $26^{\text {th }}$. Moreover, other measures are being taken at the same time that deteriorated still more the labour market as expanding without limits the facilities for temporary jobs and enlarging contracts of workers in practices up to 30 years of age.

As it could only be expected those measures have improved the public deficit but it might be that the patient will die with the cure. As it is also well known the consequences of these facts have a double character: on the one hand the populations of these countries are submitted to drastic programs that hurt many of them substantially, especially the poorer and weaker ones but not only them because most part of the population, including the middle classes, are being seriously affected, and on the other hand, to most of us our analysis show that those programs will not solve the problems that have led to the economic and debt crisis because they are unable to generate growth and on the contrary, they are creating a further recession in our economies. Clearly supply 
economics is no the medicine for our problems, and the situation generated by those policies will only increase our deteriorated situation, as it is being shown in the economies of all the countries rescued until now, and especially in Greece.

\section{The role of the European Union in Spanish crisis management}

As for the role of the EU at the crisis in relation with Spain (and I guess the situation in the other periphery countries is similar), we have already said that in the first part of the crisis the presence of the EU was not felt much, except for the monetary rescue policy of the ECB. It is only after the second meeting of the G-20 after the crisis that the Union presented its first rescue program and all of us know that only 60,000 million euro came from Union funds, while the other 170,000 million euro were the sum of national programs.

It can be said that only when the euro has been into question mainly because of the debt of the periphery countries that the Union has started to react more actively. ${ }^{17}$ In this reaction the role of global financial markets has been paramount as well as that of the IMF, but I think that the philosophy of the Union decision makers as well as that of the leaders of the member countries (all of them but those of the more powerful countries as France and Germany, even The Netherlands and Austria are more relevant ${ }^{18}$ ) goes in the same direction and the consequences of that cannot be other than

17 As well as the heavy weight for the private banks of the central countries, especially France and Germany, of the debts of the peripheral countries.

18 The United Kingdom seems to be missing in all this events siding with its American friend and still more with the interests of the city. 
the imposition of extremely tough measures of a deep post-neoliberal character (?) upon the populations of the countries of the Union - of course the periphery countries more but the other countries have not been dispensed either -. Since 2010 the Union seems to have been impelled to take a great number of rather hectic measures in order to maintain the euro and the survival of the Community (6 measures for Governance, Competitiveness Pact, Pact for the Euro, ...). It is not clear they will achieve its objectives. As it is said in The Financial Times:

'Attentiveness and goodwill can avert the sort of crisis that arises from weak responses to lesser problems, but the sources of global instability - high debts, unbalanced trade, uneven growth, easy monetary policy and restive voters - could create problems that leave the authorities impotent, even if the current is not yet strong enough to break the defenses' (The Lex Column, 2010/8/13).

Some of these measures are directed to support the euro, the financial systems of the member countries and their stock exchange. Also the big banks of the central countries that have invested in the weaker countries and find themselves implicated with the problems of debt now: Thus the European Financial Stability Facility (FEEF) and the project of its maintenance in time (MEDE). Also, recently with the new alarm about the fears of a renewed recession, the ECB has resorted to buy Italian and Spanish debt which has substantially eased the financial situation of both countries ${ }^{19}$. But in exchange for that support the EU compels the weaker countries (but more

19 But not enough in the opinion of C. WyPLOsz, professor of Economics at the Graduate institute of International studies at Geneve that considers that: 'The ECB has to take a very strong position and guarantee all public debt. They have to get out their atomic weapons'. The Financial Times, 13/8/2011. 
and more countries might be included in the qualification of 'weak') to establish a set of adjustment measures we have already commented above, that only lead to the disadvantage of growth and recovery of the economy of the periphery European countries and damage very seriously the well-being of their populations. They do not seem to be enough to satisfy what are called markets nowadays since any change in the situation rises again all the alarms. The spectrum (?) or the reality of the crisis is here again ${ }^{20}$.

In August we see how the stability of the system after the crisis is extremely dubious and vulnerable. What is seen as the failure of the American representatives and the danger it poses for the recovery of the US economy on the one hand, and the expectations which are built - with the very valuable help of the rating agencies - about the difficulties for growth of the European countries and for satisfying the debt facilitates still more the speculative moves against not only the poorest countries of the eurozone but also the central ones renewing strongly all the fears ${ }^{21}$.

So much so that four countries of the Union - Belgium, France, Italy and Spain - on the $12^{\text {th }}$ August start trying to limit somehow the power of speculation, limiting the short selling operations of 60 institutions for 15 days $^{22}$. A very light, smooth and 'limited limitation'23. May we hope that it will

${ }^{20}$ For countries like ours, we have never come out of the crisis.

21 R. Milne and R. Wigglesworth: "Investors retreat turns to 'stampede": "An imperfect storm of downgrades, rumours, lacklustre macroeconomic data and the eurozone debt crisis transformed a retreat by investors into something approaching a stampede'. The Financial Times 13/8/2011.

22 But Credit default swaps CDS are not affected. Curiously it seems Germany had already forbidden previously this type of practices unilaterally.

${ }^{23}$ It is rather infuriating and sad to see that only when more important countries like Belgium and Italy and especially France are concerned 
be only the beginning for better policies from a Union that seems to be frozen, unable to deal with its problems, absolutely dominated by the global capitals?

Writing mid-August, after the Merkel-Sarkozy $16^{\text {th }}$ August disappointing meeting to deal with the new "near panic' situation generated because of the fear of a renewal of the recession in both sides of the Atlantic, it can be said that even if the proposals and practices of the ECB to buy Spanish bonds certainly eases the situation of the country, in relation with the markets, the new proposals of the Franco-German axis are still more scary for Spain: Besides the negative consequences that lack of growth in the main European countries of the Union may have for Spanish exports and the Spanish economy, the measures in themselves are very worrying since they make tougher the austerity requirements in an endless process that seems to induce more and more exigent and unjust measures every day, require that budget balance be written in the Constitutions of the eurozone countries ${ }^{24}$ and propose even to retire ('to suspend' in politically correct language) the European funds to those countries that do not fulfil the requirements of 'fiscal stability'25. Once more the

will some measures, whatever limited start to be taken: 'On Wednesday, after wild rumours swept the French markets and the big banks shares fell, regulators became concerned' and 'Only a handful of states in May backed German proposals for a bank on naked sovereign CDS trades'. 'Naked' means that you haven't even borrowed the stock you are shorting. The Financial Times, 13/8/2011.

24 Spanish political leadership - both in government and opposition - do not want even to mention amending the Constitution for internal reasons, therefore for that proposal they have achieved the requirement be 'to include in the Constitution of in a major legislative norm'

${ }^{25}$ That is nothing but an euphemism for fiscal limits and austerity. As we have said above the position of the country leading the Union would be funny were it not so dangerous, because it is not so many years that both France and Germany surpassed the limits of the Stability and 
weakest will have to pay for their problems. As for the more positive proposal - a tax on financial transactions - it has to be seem how and when it will be structured, implemented and the funds utilised.

As for the proposals for the creation of an European economic government for the eurozone it has to be said that it is extremely dangerous, and we stress that point, as far as the philosophy of the Union and its policies go the way they are going: so far the little space that is left to the Governments of the member countries might be used for progressive policies in some cases (it is not the case in Spain) but at least is being used for social forces to resist and fight the policies at present, while if the policies are enacted from the Union the little room for manoeuvre that now exists will disappear Also, the news that some member countries (Finland for the time being, but it seem Slovakia and Slovenia, Austria and the Netherlands are also planning to demand similar agreements) are requiring from Greece of bilateral commitments in order to obtain their agreement for the second rescue show the situation is really reaching an incredible level ${ }^{26}$. Measures increase every day and seem to be more irrational ever except form the point of view of the most naked concept of money, money, money. It seems as if under the present problems everybody with some power has lost their senses and only thinks in terms of every man (every one with power) for himself. Sometimes one has the impression of a complete debauchery of the European Union. Is it possible to assert that there is any type of Union observing these conditions?

Growth Pact and no doubt they will do it again if necessary, even if they can cover it up afterwards with specific directives.

26 It seems Germany is not prepared to accept these bilateral agreements, but other informations assert that Finland has already signed it with Greece. The situation is very confused 
As far as Spain is concerned it seems to us that it can be said that this Europe, the neoliberal and post-neoliberal Europe that has presided the Community since our accession has not been of great value to our country. It may be that our economy has grown for a few points more than if we have not joined, and even so is not certain ${ }^{27}$, but it seems to us that belonging to the Union has rather contributed to exacerbate all the disequilibria we traditionally had: our productive capacity has been concentrated in very few segments of medium value added and low qualified labour and many small firms of poor technological capacity remain, while a substantial part of the more dynamic capital goes abroad, our external balance has deteriorated heavily even with increased exports because of the increase of imports, many of them impelled by the foreign ownership of our main industries, and we are unable to gear our external sector because of the euro. On the social side we have already said enough about the Spanish deterioration and lag in social issues. In particular, the Union policies enacted allegedly because of the debt crises are very heavily deteriorating our economic and social situation. The prospect of more European power is not that venturous for the periphery. No surprise that most people in the country that used to be deeply European reject it now. This Europe is negative for Spain and the Spanish population. Either we transform it in a different institution or we shall have to think in other ways.

It seems incredible that financial capitals have taken the world at ransom. They are now more than ever the masters of the world and shamelessly so. They are taking advantage of it without any concessions. What sort of future may we envisage after this situation? What has late capitalism to offer to the populations of the world?

27 The loss of growth due to austerity policies since the Maastricht Treaty would have to be compared with the possible growth due to the membership of the Union 


\section{The effects of the crisis}

\subsection{Effects on the population}

Unemployment is the key problem for the Spanish population. Together with uncertainty for those who are working and the degradation of wages, unemployment is higher than ever: 5 million workers, $21 \%$ of the working population, in some regions above $30 \%$, and in the Autumn it will probably increase; unemployment of the youth is above $42 \%$ and many of them think of emigration if only they knew where; temporary work becomes the norm, wages of the 'privileged' that have a job lag behind, more and more people is evicted and remain in debt for the future ${ }^{28}$, social services deteriorate heavily, there is no way where an improvement is contemplated. The idea that the authorities try to transmit 'it will improve next year' is totally discredited, as well as politics, politicians and 'institutional' unions ${ }^{29}$ from which very little help is expected. A general atmosphere of hopeless, fear for the future and despair dominates the country.

It is worth mentioning that among many elements that are suffering of the austerity measures the ones more heavily affected are those that constitute the nucleus of the wel-

${ }^{28}$ Spanish laws make that the person that is evicted does remain in debt for the rest of the amount of the original debt. Since the value of apartments is much lower than the original in the process of eviction very often debtors lose their apartment and are indebted to the banks for a heavy amount.

${ }^{29}$ In Spain there are two main Unions - CC.OO. founded by the Communist Party during the Franco era but now very moderate, and UGT, the socialist union - that are very amenable to the will of the government and even of enterprises, that the workers consider the 'institutional or official unions', and a number of small unions catering for specific groups of workers or more radical workers. 
fare state. And in particular it is worth dealing attention to the enormous and very good publicity campaigns orchestrated around the fact that there is no money for social services, maintaining social services are infeasible because the crisis but also because the increasing aged population (pensions), the increasing cost of health services and bad use of them by the population (health), the better quality of private education, and the increase in the cost of social assistance. No need to elaborate that there is a fierce attack in all the social services and the aim is to diminish them using the crisis as the argument to justify it. In these campaigns it is not possible to find any reference to the need to increase the public income with better taxation. Income is treated as fixed and impossible to be altered while only the decrease in expenditure is considered, showing very clearly that the problem is not the lack of funds but the willingness to deteriorate de welfare state in order to led the population to the private services. The worst is that these campaigns have achieved their aims and big parts of the population are convinced that there is no money for the social services and seem prepared to pay privately for education, health and pensions. 
Box 2. - The problem of the black economy. Spain has 5 million people unemployed, 1,3 million families with all of its member unemployed and many unemployed without subsidy as well as four million people estimated working in the submerged economy in very precarious conditions of wages and stability, besides not benefiting from any social rights. It will be no surprise for anyone to know that many unemployed people work in the black economy for survival. But in the Pact for the Euro it is required from the countries to eliminate the black economy. Have the leaders of the Union for a moment contemplated the extremely difficult position in which they place subsidyless unemployed workers and also the governments of countries like ours imposing now these conditions? It would mean workers are denied the last possibilities of getting some income, scarce and humiliating as it can be and the risk of social upheaval increasing enormously. No need to add that employers of submerged workers are not prepared to legalise them in the slightest. Therefore the Governments are placed in an impossible position. As usual, our Government has fulfilled the legal requirement enacting a law allowing employers to legitimise illegal workers without penalty until $31^{\text {st }}$ July, but we are in August and there is extremely little movement, if any, on those lines. It could not be otherwise in our conditions. It seems that the Union decision makers ignore totally the sort of real conditions in which the member countries find themselves. They should care for the coherence of their norms.

\subsection{No growth and lack of demand}

In these circumstances private demand diminishes and exports and tourism, although improving, are far from being enough to sustain economic activity. Since the government is decreasing its expenditure and planning to continue on it -current and investment- there is no demand for the productive activity and growth scarcely resumes: GDP increased only 
a $0,7 \%$ in last trimester, external demand increased $2,6 \%$ but domestic demand fell down 1,9\% (Source: INE, 2011). Spain never came out of the crisis and at present is getting more and more in a situation of 'low activity disequilibrium' that makes extremely difficult to envisage a real improvement of the situation for the population, even for industry and services (tourism suffers a lot from temporality and low expenditure tourists), for employment and the social rights. Spain cannot grow and improve its unemployment with these policies that is absolutely clear. Nominal growth of recorded wages has been of $0.5 \%$ in 2010 (inflation rate about 3\%). Nevertheless all that does not impede that companies have increased their profits by $4.1 \%$ on average and big banks had 15,300 million $€$ profits.

The measures that are being taken, rhetorically in order to pay the debt, are far from constituting a solution to the problems of the economy. With these measures we all know it is impossible to grow, generate investment, stimulate a better productive model: improvements in productivity except for dismissal of workers become impossible and competitiveness seems an illusory word. On the contrary they lead to make the recession permanent and deeper. What is still more, in these conditions, with lack of growth, heavy unemployment and a very weak productive structure it is also impossible to think of paying the debt and even paying for interest on it might be difficult.

One word about the reaction of the people: neoliberalism does not imply only an economic and social policy, it also integrates a relevant value system - individualism, consumerism, the worthwhile of capitalism and so on - and our societies have been impregnated from them. The negative effect of the fall of the State socialism of the Eastern countries did also have an effect. 'There is no alternative' was an intelligent slogan. When in the first 2000s, Sr. Aznar, chef of the Spa- 
nish government said: "España va bien”, many people agreed with him. They were feeling reasonably content. Afterwards with the crisis they became worried and scared about the conditions of the labour market and employment but also convinced that there is nothing that can be done to modify the economic elements, the publicity about the power of the markets being ample and predominant. Therefore people was unhappy but very quiet (as so many times in history), without any social answer or at most very specific and limited protests of the dismissed workers when a factory closed. And politicians and markets have taken advantage of it and took advantage to enact the very severe policy we are commenting upon. It seemed unbelievable that workers and people did not react more but so it has been.

\section{A glass ball for the next decade and after}

If the measures taken are not going to solve the problems of the countries concerned, why are these measures taken then? Do the decision makers still believe that saving in other expenses will allow to pay for the debt? That is really imaginative because if only they compare the savings the country may gather at present and the amount of the debt the difficulty is evident; moreover it shows a worrying trend towards very short term considerations since if they are deteriorating heavily the economy of the country and its productive power it will take a very long period to recover with very serious consequences; or, is it possible that decisions makers have been persuaded that supply economics work: that giving all facilities to enterprises - low wages, 'very flexible' conditions of work, low taxes, scarce regulations, etc. - growth and employment will resume. But the evidence points directly in other direction: neither in the periphery nor elsewhere, 
perhaps with the exception of Germany, supply conditions have led to growth in the situations of the countries after the 2008 crisis and the countries that have suffered less or recovered better from it are not the countries that have followed more faithfully the terms of supply economics. There is only one third reason left: the argument of the debt is a very good argument to convince the populations that all these measures are unavoidable and have to be taken. That allows for very wide and ambitious restructuring of the economy in favour of the big global capitals (that include also the national capitals) allowing them to take any course of action they believe may be good for their interests (always short term ones).

We are witnessing an enormous operation of the big economic powers to advance towards the domination of the workers and populations of the central countries. To conform according to them macroeconomic policies, productive systems, labour relations, destroy the welfare state in favour of private capitals. In a word, build up a new phase of capitalism in which only profits for a minority are the relevant variable and everything else has to submit totally to it. The problems of the economies may require substantial changes in the economic system but they do not have to be the ones that are being taken. They are taken because they favour capital and make labour more submitted and malleable and that in a permanent manner. We cannot expect a recovery in a couple or tree of years, but a new epoch is starting in which the populations will be totally subordinated.

In Spain the people is scared and very pessimistic. For a couple of years they have been waiting for a recovery but they now see it is not likely to come but at least, we are told, in about fifteen years. And for many people the situation is desperate: With five million people unemployed, among them $46 \%$ of the young, four million in the black economy, the welfare state being conspicuously destroyed, all subsidies and 
support eliminated...Perhaps the feelings are well expressed by one of the most important commentators (a rather progressive social-democrat but within limits) of the El Pais, the most important opinion making paper of the country:

What will it happen from autumn onwards in a country like Spain if, for instance, in the next five years the economy will not grow or it will grow below the employment creation level? How can a society survive when almost half of its youth is unemployed; it has more than one million households with all its members unemployed; the number of long term unemployed keeps rising - and also, little by little, they are losing all kind of policies of support for the unemployed and social benefits that exist in some regions -, they become decapitalized and aging; in a society where every month is increasing the number of breadwinners, a direct synonymous of increasing poverty? ... the most repeated concept in media headlines this summer has been "fear"... fear to the risks that threaten the social order that secures the means of living (wages, employment), survival (poverty, indigence) or the position in the social hierarchy (Joaquin Estefania. El País. 18-8-11).

But not only so but the people with good jobs and the middle classes are also very worried: their wages are going down, indirect taxes going up, they feel they have to pay the more and more for the social services, and especially there is total uncertainty about the durability of jobs and the prospects for their children are grim.

For many people the 'markets', they do not know nor understand and the politicians are the culprits. Nobody believes in politics any more. Because they are not able to solve the problems but also by the many instances of corruption and high living that have appeared in the last years from all sides of politics. People is totally disaffected from institutional politics and also from the main unions. In the last municipal elections 
the governing party (socialists) lost most of the local power and all predictions for the next general election that will take place in November are of a very strong victory of the opposition party (Partido Popular, conservative). It is normal than in period of crisis the party in power loses the power, and it has to be said that the socialist party has not had any good policy to confront the crisis and has faithfully submitted to the economic and Union powers without any resistance and enacted a tough post-neoliberal policy, but it does not seem that with the new conservative government things will improve. The other way round, even if at the nucleus of economic and social policy the trend will be the same and no big changes are to be expected for what is known of their philosophy and their practice, only a deterioration of policy regarding the populations is to be expected. Will the business world sympathise more with them, react positively and invest? It does not seem likely since the business world was already very comfortable with the present government. The outlook is grim for the economy and above all for the population.

In spite of all that we may end with a more optimistic outlook: it is known that since May this year, young and not so young people have started to react. Thousands of them gathered in the main public squares of cities and towns to protest. Many different brands of people gathered and spontaneously gave rise to protests: new young people angry because the general situation (Indignados), others because of the fake democracy we are having (Democracia real ya), others because the lack of opportunities (Jóvenes sin futuro), and many others just because they shared anger. Also the social movements that already existed have integrated themselves into the groups and have been very useful to help to lead to a more political content of the gatherings. The movement is known by many names but perhaps $M-15$ because of the day it all started is the most embracing one. Against all expectations they stayed 
there for a long time, debated and discussed many aspects of their lives, politics and social issues with very ingenious and very interesting horizontal forms of doing things (assemblies without leaders), helped by social nets. In spite that they manifested and acted with an extreme pacifism, they also had to quarrel with a 'peacemaking police' but public opinion is totally at their side. A new feeling is traversing most of the population. Everybody is glad that at the end the youngsters have reacted and express what most of the population is feeling: Frustration and anger.

What is more interesting is that they continue. They have decided to work at local level and the local assemblies have been converted into district gatherings with very high attendances. Nobody knows what will come out of that movement. They are so different of most of political and social work taking place until now that it is difficult to assess their future. But for the time being they have reacted, shown their rejection of the present situation, express their frustration and anger, but also they brought us a little hope.

\section{ANNEX: SOME SPANISH PECULIARITIES}

\section{The political structure and Autonomous Communities}

One word about the relevance of the political structure of the country. It is well known that in Spain three areas - the Basque Country, Catalunya and Galicia - have always reclaimed their independence or, at least a wide autonomy in their political organisation. When Franco died this was one of the very important problems of the new configuration of the country. To avoid responding only to the three regions - the first two were well known as rather disaffected to the cen- 
tral governments - a system of Autonomous Communities (AACC) was designed for all the Spanish regions, sanctioning 17 Autonomous communities in some sort of a so-called asymmetrical federal structure. It is a complex system, with 14 communities (including Catalonia and Galicia) within the general regime of regulation and the Basque Country, Navarre and Canary Islands with different regimes. ${ }^{30}$

Besides the Basque Country, Catalunya and Galicia that demanded more autonomy, a really new system for the 14 regions that historically never intended any degree of autonomy from the centre. This led to a wide reorganisation at all levels, with a redistribution of public expenditure as well as an increase in the number of politicians. During the first period - the new Constitution is of 1978 - almost everybody seemed happy with this arrangement, except for a small very centralist rightist minority; during the period of the boom - 1995-2006 - also things went smoothly because there was enough money around. Importantly, the communities within the general regime were increasingly given nation-state competences in almost all fields of government: education, health, social services, culture, economic development, and in some cases, police force. In many regions, the AACC become the level of government delivering most part of the welfare state and accounting for the workers on these fields. In contrast to the decentralisation of the expenses, the revenues to finance them stayed in the central government hands, without no transparent system such in other federal states (e.g. Germany). Indeed, in many occasions as competences of the communites grew, nation-

${ }^{30}$ The Basque Country and Navarre are "foral" communities. Though in a more complex way, basically, besides enlarged competences, they are in charge of collecting national-stat taxes, and then they negotiate (conciertos) how much they return to the central government by five years periods. Canary Islands, and the autonomous cities of Ceuta and Melilla in the African Coast have different status too. 
-state funding was lagging or getting short. In addition, many of these communities also expanded their expenditure during the boom years with more than doubtfoul policies aimed at, amongst other, pharaonic constructions, cronysm, etc. Thus it has come quite common that some communities has been always having troubles balancing their budgets.

But when the crisis and the adjustment programmes have diminished the budgets, increased debts and required austerity quite a number of forces from the right and some important economic agents are questioning the validity of this arrangement and the question of the distribution of power (and funds) is coming into the open, clearly being the forces in the right the ones prone to question the soundness of the present situation. AA.CC. are being accused of being responsible of a relevant part of the debt. In fact, the central government is pushing hard to press AACC in order to be able to fulfill the promises of deficit reduction.

However, it seems difficult to diminish their deficit because most of the social services are provided by them and most of its expenses are in personnel and delivering universal services. It is dubious if the real reason behind this attack is the deficit they represent, another route to diminish the welfare state or the centralism of important segments of power. What will be the outcome of this debate? Difficult to say but it does not seem the quarrel will be enough to change the regional organisation of the country - politically infeasible for the three main original regions and also too many regional politicians are interested to maintain their power and their posts - but it might be that some reorganisation among them and among the distribution of funds might take place. We mention it here because is one of the points of interest for many foreign observers. 


\section{The Saving Banks}

Another point of interest may be the restructuring of the Savings Banks. The Savings Banks (Cajas de ahorros) were some sort of 'para public' institutions very often established originally with some social and regional commitments and because of their organisation they are closely related to regional authorities. Since 1978 they have become in their operations more and more similar to ordinary banks but still retain part of their commitments and in general they have been important lenders to regional authorities - sometimes sponsoring absurd expensive investment projects for the sake of political prestige ${ }^{31}$ - and even to political parties. They are a very important part of the financial system of the country. In $2006,52 \%$ of deposits went to them. And they have also been very important lenders to the building industry and the mortgages to the families and even many of them had their own real estate companies. When the crisis deepened more and more 'Cajas' found themselves with high 'morosity' in their mortgages and bankruptcies in the building industries and plenty of flats to sell. Their balance sheets were full of mortgages evaluated in the original values, that is, totally falsified in order not to have to provision heavy losses. Obviously this led to many liquidity and solvency problems for many 'Cajas' that had very grave financial problems. This provided for an excellent opportunity to the Spanish Banks (always feeling strong competition from the Cajas) and especially for the Governor of the Spanish Central Bank to organise a privatising operation to convert in banks many of the Cajas

31 For instance they financed the País Valenciano regional authorities to build an airport in Castellon that still does not have the authorisation to fly, also to the same authority the building of Terra Mítica, a failed project thematic park (like Disneyland), the financing of the motor races (Formula 1) and quite a number of similar undertakings besides. 
of the country under the argument of the inefficiency that political elements in the board of the Cajas made them very inefficient. The Bank of Spain proposed a system by which Cajas could become hybrid entities becoming partial owners of banks created by the Cajas, with the help of public funds and opening to private capital. Out of 45 Cajas, at present only 17 remain but most of them converted into banks after a rescue operation that is estimated is costing the public purse for the time being about 16.000 million euros ${ }^{32}$ by means of a sophisticated financial operation. Some Cajas complain that the operation was unnecessary (although others were practically bankrupt) but most of them have been restructured to become Cajas-Banks institutions (with the bank facet taking the lead), some others claimed that they could survive by themselves, a few of the more healthy Cajas have chosen to remain as they were and a couple of very powerful and financially sound ones have taken advantage of the new law to restructure themselves. That is, a serious financial problem of a number of Cajas, has been used as a good reason to privatise half of the Spanish financial system that had accumulated a very substantial 'parapublic' patrimonial wealth. In Spanish we say 'operación redonda' (round operation).

32 Public authorities say they are lending the money to the Cajas-banks but it is not clear if those funds will ever be refunded and when. 
COMMUNICATION FOR $17^{\mathrm{TH}}$ WORKSHOP ON ALTERNATIVE

ECONOMIC POLICY IN EUROPE, VIENNA, SEPTEMBER 2011

The records of the Spanish economy in 2010-2011

\begin{tabular}{|c|c|}
\hline - Unemployement: & $\begin{array}{l}\text { More than } 4,800,000 \text { unemployed, } \\
21 \% \text { of working population, June } 2011 \text {; } \\
46 \% \text { among young workers; June } 2011 \text {. } \\
1,370,000 \text { families with all their members } \\
\text { unemployed }\end{array}$ \\
\hline - Evictions & $\begin{array}{l}300,000 \text { in } 2010 \text { because of lack of mortgage or } \\
\text { rent payment: }\end{array}$ \\
\hline - Black economy & $\begin{array}{l}17 \% \text { of GDP } \\
=\text { a fiscal fraud of } 30,000 \text { million } € \text { a year } \\
=20 \text { times the Government savings with the } \\
\text { pension freeze } \\
=4 \text { million workers } \\
\text { (other estimates increase the black economy to } \\
\text { the } 20-22 \% \text { of GDP) }\end{array}$ \\
\hline - Business profits & $\begin{array}{l}\text { the } 35 \text { biggest enterprises of the IBEX (Stock } \\
\text { exchange) had profits of } 49.881 \text { million } € \text { in } 2010 \\
\text { Increase of } 24.5 \% \text { over } 2009 \text {. } \\
\text { Business profits increased } 4.1 \% \text { and wages } 0.5 \% \text {. } \\
\text { Big banks had profits of } 15,300 \text { million } €\end{array}$ \\
\hline $\begin{array}{l}\text { - Remunerations } \\
\text { of high directors }\end{array}$ & Those of the IBEX35 increased $20 \%$ on average \\
\hline - For instance: & $\begin{array}{l}\text { Telefónica has increased profits a } 30,8 \% \text { in } 2010 \\
\text { to } 10,167 \text { million } \\
6,000 \text { workers were dismissed to keep competi- } \\
\text { tiveness }\end{array}$ \\
\hline
\end{tabular}

Source: Adapted from I. Escobar: 'La economía bate records'. Público 3/3/11. 


\section{REFERENCES}

Aalbers, M (2011). Place, Exclusion and Mortgage Markets. Oxford/ /Blackwells.

Ayala, L. and Sastre, M. (2007). Políticas redistributivas y desigualdad, Información Comercial Española, 837:117-138

Banco de España (2011), La Balanza de Pagos de España 2010. Madrid: Publicaciones del Banco de España.

Chislett, W (2008). Spain Going Places: Economic, Political and Social Progress, 1975-2008. Madrid: Telefónica SA.

Etxezarreta, M. (ed) (1991). La reestructuración del capitalismo en España. Barcelona: Editorial Icaria.

The Financial Times (2006). Property Special Report, March.

Harvey, D. (1999). The Limits to Capital. London: Verso.

- (2010). The Enigma of Capital and the Crises of Capitalism. Oxford: Oxford University Press.

Myro, R. and Gandoy, R. (2009). Sector industrial. In Garcia-Delgado, J. L. and Myro, R. (ed.), Lecciones de Economía Española, 9th edition, Madrid: Thomson-Reuters.

— y Fernández-Otheo, C. (2004). La deslocalización de empresas en España, la atracción de los PECO, Información comercial española, n.818, pp. 185-201.

Observatorio de Energía y Sostenibilidad en España (2008), Informe basado en Indicadores. Madrid: Cátedra BP de Energía y Sostenibilidad, Universidad Pontificia de Comillas.

Royo, S. (2009), Reforms Betrayed? Zapatero and Continuities in Economic Policy. South European Society and Politics 14(4): 435-451

TAIFA (2006), Del pleno empleo a la plena precariedad. Informes de Economía, $n^{\circ}$ 3. Barcelona: Seminario de Economía Crítica TAIFA. Available in: < http://seminaritaifa.org >

- (2008), Auge y crisis de la vivienda en España. Informes de Economía, n. ${ }^{\circ}$ 5. Barcelona: Seminario de Economía Crítica TAIFA. Available in: < http://seminaritaifa.org >

- (2010), La crisis en el estado español: El rescate de los poderosos. Informes de Economía, n. ${ }^{\circ}$ 7. Barcelona: Seminario de Economía Crítica TAIFA. Available in: < http://seminaritaifa.org >

— (forthcoming), La crisis de la deuda. Informes de Economía, no 8. Barcelona: Seminario de Economía Crítica TAIFA. Available in: $<$ http://seminaritaifa.org $>$

Turrión, J. and Velázquez, F. (2007). La ampliación de la UE hacia el este: Los previsibles efectos sobre la economía española en los flujos comerciales y de inversión extranjera directa. In Zubiri, I. La ampliación al este de la Unión Europea. pp 405-478. Madrid: Academia Europea de Ciencias y Artes. 
Euforia e crise (profunda) na economia espanhola: o papel da UE nessa evolução

Resumo: Nos últimos vinte anos a Espanha passou por um período de rápido crescimento seguido de uma crise profunda. Até 2007, foi chamado o 'milagre económico espanhol' e agora é o país com taxa mais elevada de desemprego, entre várias outras perturbações muito sérias.

A presenta crise económica trouxe com ela vários problemas para a economia e para o país, que estão a revelar-se de difícil solução. A Espanha tornou-se uma parcela muito relevante da periferia europeia e o problema da sua dívida, em especial a dívida externa, está a tornar-se um elemento-chave das políticas atuais. Todo este processo tem sido desenvolvido à volta da (e não pode separar-se da) integração da Espanha na União Europeia e na Eurozona.

O propósito deste artigo é o de explorar as razões de tal evolução, analisando especialmente os acontecimentos dos últimos dez anos, as políticas que foram incrementadas para enfrentar a crise, a influência da UE sobre elas e, em particular, as consequências dessas políticas para a população. Será também ensaiada uma análise prospectiva sobre as consequências económicas e sociais de tais políticas para o futuro próximo do país.

Palavras-chave: Economia espanhola, Crise económica, União Europeia, Desemprego

Abstract: In the last twenty years Spain has experienced a period of rapid growth followed by a very deep crisis. Until 2007, it was named 'the Spanish economic miracle' and now it is the country with the highest unemployment rate in the EU amongst many other very serious troubles. The present economic crisis has brought severe problems to the economy and society of the country which are proving to be rather intractable. Spain has become a very relevant part of the European periphery and the problem of its indebtness, especially external debt, is being adduced as a key element for today's policies. All this process has been developed around, and cannot be detached from, Spain's integration to the European Union and the Eurozone.

The purpose of this paper is to explore the reasons for that evolution, especially dealing with the events of the last ten years, the policies 
that have been implemented to deal with the crisis, the influence of the EU upon them and, in particular, the consequences of those policies for the population. A very tentative view about what are the economic and social prospects of the country for the near future will also be intended.

Keywords: Spanish Economy, Economic Crisis, European Union, Unemployment.

Miren Etxezarreta

Universitat Autònoma de Barcelona

Francisco Navarro

Universitat Autònoma de Barcelona

Ramón Ribera

Universitat Oberta de Catalunya

Victòria Soldevila

Universitat Rovira i Virgili

All members of the Seminario de Economía Crítica TAIFA 